\title{
EROSI DAN TINGKAT BAHAYA EROSI PADA PERTANAMAN KENTANG
}

\section{(Erosion and the Level of Hazard of Erosion on Potato Growing)}

\author{
Saida $^{1}$, Abdullah ${ }^{1}$, dan M. Ilsan ${ }^{2}$ \\ ${ }^{1)}$ Program Studi Agroteknologi Fakultas Pertanian, UMI Makassar \\ ${ }^{2)}$ Program Studi Agribisnis Fakultas Pertanian, UMI Makassar
}

\begin{abstract}
This study aims to predict the erosion and determine the level of hazard of erosion on potato growing, its implementation in the Village Pattapang District of Gowa. The method used for the prediction of erosion is USLE and determination of erosion potential using the approach byt he Department of Forestry. Results obtained by the prediction of erosion on potato crops ranged from 3.34 to 223.11 tonnes /ha/ year and the low level of erosion on SL III 4 and 5, medium level on SLIII2, heavy level on SL III 3, and very heavy level on SL III 1.
\end{abstract}

Keywords: erosion, hazard of erosion, planting potatoes.

\section{PENDAHULUAN}

Sumberdaya alam berupa vegetasi, tanah, dan air mempunyai peranan yang penting bagi kelangsungan hidup manusia. Pemanfaatan sumberdaya alam yang tidak sesuai dengan daya dukungnya dapat menyebabkan terjadinya erosi, banjir, kekeringan, pendangkalan sungai dan waduk serta saluran irigasi (Asdak, 1995). Tekanan yang besar terhadap sumber daya alam oleh aktivitas manusia, salah satunya dapat ditunjukkan oleh adanya perubahan penutupan lahan dan erosi yang begitu cepat. Pengelolaan DAS dengan permasalahan yang kompleks memerlukan penanganan secara holistik, integral, dan koordinatif.
Tanah termasuk sumberdaya alam yang terbatas yang sangat penting bagi kehidupan manusia. Oleh karena itu pemanfaatannya harus dilakukan secara bijak. Artinya dalam pemanfaatan tanah harus ada pemeliharaan dan pencegahan terhadap faktor-faktor penyebab kerusakan tanah berdasarkan prinsipprinsip konservasi. Di daerah-daerah yang tidak menerapkan teknik konservasi tanah apalagi pada lahan berlereng seperti di hulu daerah aliran sungai, sering timbul dampak negatif pada lingkungan baik pada daerah dimana terjadi erosi (on site), maupun pada daerah hilirnya (off site) berupa sedimentasi, kekeringan dan kebanjiran. Fenomena degradasi 
lingkungan seperti banjir, erosi, longsor, dan sedimentasi di musim hujan serta kekeringan di musim kemarau sudah terjadi dengan frekuensi yang semakin sering dan intensitas yang semakin parah (Sinukaban, 2008).

Pendekatan penataan dan pengelolaan kawasan daerah aliran sungai dapat dilakukan untuk mengatasi masalah penurunan produktivitas sumberdaya lahan. Pemantauan ini perlu dilakukan, antara lain mencermati konsep dan pengelolaan daerah aliran sungai sebagaimana tertuang dalam Undang-Undang No. 7 Tahun 2004 tentang Sumberdaya Air. Dalam Undang-Undang tersebut, pada pasal 1 ayat 11 dinyatakan bahwa daerah aliran sungai (DAS) adalah suatu wilayah daratan yang merupakan satu kesatuan dengan sungai dan anak-anak sungainya, yang berfungsi menampung, menyimpan dan mengalirkan air yang berasal dari curah hujan ke danau atau ke laut secara alami, yang batas di darat merupakan pemisah topografis dan batas di laut sampai dengan daerah perairan yang masih terpengaruh aktivitas daratan. Sedangkan pengelolaan DAS adalah upaya dalam mengelola hubungan timbal balik antar sumberdaya alam dengan sumberdaya manusia di dalam DAS dan segala aktivitasnya untuk mewujudkan kemanfaatan sumberdaya alam bagi kepentingan pembangunan dan kelestarian ekosistem DAS atau pengaturan tata guna lahan atau perencanaan penggunaan lahan (land use planning) dengan indikator kunci (ultimate indicator) kuantitas dan kualitas aliran sungai pada titik pengeluaran (outlet) DAS (Murtilaksono, 2009).

Erosi merupakan masalah utama di hulu DAS Jeneberang. Dari penelitian sebelumnya diketahui bahwa erosi yang terjadi di hulu DAS Jeneberang sudah sedemikian parah sehingga telah menimbulkan lahan kritis dan lahan tidak produktif. Luas lahan kritis di DAS Jeneberang adalah seluas 53.471 ha dan cenderung terus meningkat (BP DAS Jeneberang Walanae, 2003). Kondisi tanah yang peka terhadap erosi, topografi wilayah yang pada umumnya miring sampai sangat miring dan intensitas hujan yang tinggi menyebabkan laju erosi sangat tinggi. Akibatnya, produktivitas lahan semakin menurun.

Kondisi biofisik wilayah DAS Jeneberang, dalam hal ini morfologi, topografi, kemiringan lereng serta curah hujan, memang secara alamiah mempunyai CT potensi erosi yang sangat besar ataupun berpeluang besar memberi kontri- 
busi terhadap terjadinya erosi, banjir, sedimentasi, dan kekeringan. Sekitar 46\% wilayah DAS Jeneberang mempunyai topografi bergunung sampai berbukit dengan kemiringan lereng lebih besar dari 40\% (BP DAS Jeneberang Walanae, 2003). Lahan dengan kemiringan lereng lebih dari $30 \%$ adalah sekitar $53 \%$ dari luasan areal lahan, dan ada 18\% lahan dengan kemiringan lebih dari 50\% (Nurkin, 2005). Hasil pengukuran erosi di hulu DAS Jeneberang menunjukkan kisaran 1,10 ton/ha/tahun sampai 4.989,69 ton/ha/tahun (BP DAS Jeneberang Walanae, 2003). Tingkat bahaya erosinya berkisar dari sangat ringan sampai sangat berat. Hasil penelitian Zubair (2005) menunjukkan bahwa penggunaan lahan sebagai tegalan di hulu DAS Jeneberang mengakibatkan terjadinya erosi sebesar $2.860,79 \mathrm{ton} / \mathrm{km}^{2} / \mathrm{tahun}$.

Komoditas hortikultura merupakan salah satu produk pertanian yang penting bagi ketahanan pangan nasional. Sebagian besar usahatani hortikultura khususnya sayuran memiliki keunggulan kompetitif dan komparatif karena efisien secara finansial dalam pemanfaatan sumberdaya domestik (Arsanti dan Boehme, 2006). Kawasan DAS bagian hulu mempunyai iklim yang memenuhi persyaratan optimum untuk pengembangan berbagai komoditas hortikultura buah-buahan dan sayuran. Beberapa hasil penelitian menunjukkan bahwa secara finansial usahatani kentang memberikan keuntungan lebih besar dibandingkan dengan usahatani tanaman pangan maupun kebun campuran. Disisi lain, usahatani kentang sering dituding tidak ramah lingkungan, karena potensi terjadinya erosi pada lahan relatif tinggi, terutama pada lahan berlereng relatif curam dengan usaha pencegahan erosi yang kurang memadai (Dariah dan Husen, 2006).

\section{METODE PENELITIAN}

Penelitian ini dilaksanakan di Kecamatan Tinggi Moncong Kabupaten Gowa, berlangsung dari bulan Mei sampai Oktober 2013.

\section{Sumber dan Teknik Pengambilan Data}

Lokasi pengambilan sampel didasarkan pada peta satuan lahan (unit lahan) yang dihasilkan dari overlay peta dasar. Pengambilan contoh tanah menggunakan Stratified Random Samplling untuk masing-masing unit lahan. Jumlah contoh tanah untuk keperluan analisis sifat fisik tanah sangat tergantung pada banyaknya satuan lahan. Contoh 
tanah untuk analisis sifat fisik diambil dengan menggunakan ring sampel.

Data biofisik lahan yang diamati meliputi curah hujan, sifat-sifat tanah yang meliputi struktur tanah, tekstur tanah, kandungan bahan organik, permeabilitas, panjang dan kemiringan lereng, penggunaan lahan, jenis-jenis vegetasi penutup tanah dan tindakan konservasi atau pengelolaan tanah.

\section{Metode Analisis Data}

\section{Prediksi Erosi}

Pendugaan besarnya erosi yang terjadi di lahan pertanian dilakukan menggunakan pendekatan persamaan prediksi kehilangan tanah secara komprehensif dengan pendekatan yang dikemukakan dalam The Universal Soil Loss Equation (USLE). Persamaan USLE yang telah direvisi menurut Smith et al. (2007) adalah :

$$
\mathrm{A}=\mathrm{R} \times \mathrm{K} \times \mathrm{LS} \times \mathrm{C} \times \mathrm{P}
$$

Dimana :

A : erosi yang mungkin terjadi (ton/ha/tahun)

$\mathrm{R}$ : faktor curah hujan dan aliran permukaan (erosivitas hujan)

$\mathrm{K}$ : faktor kepekaan erodibilitas tanah.

LS : faktor panjang lereng dan kemiringan lereng.

C : faktor pengelolaan penutup tanah (tanaman).

$\mathrm{P}$ : faktor tindakan pengelolaan tanah (konservasi tanah)

\section{Faktor Erosivitas Hujan.}

Rumus persamaan yang digunakan untuk menghitung faktor erosivitas hujan yaitu yang dikemukakan oleh Lenvain (1975) dalam Arsyad (2006) mendapatkan hubungan antara $\mathrm{EI}_{30}$ dengan curah hujan tahunan $\left(R^{\prime}\right)$ sebagai berikut :

$$
\begin{aligned}
& \mathrm{R}=\left(\mathrm{EI}_{30}\right) / 100 \\
& \mathrm{EL}_{30}=2,34 R^{, 1,98}
\end{aligned}
$$

Dimana:

$\mathrm{R}$ : Erosivitas hujan

$\mathrm{EL}_{30}$ : Interaksi energi dengan intensitas hujan maksimum 30 menit

$R$ ': curah hujan tahunan

\section{Faktor Erodibilitas Tanah.}

Nilai $\mathrm{K}$ atau erodibilitas tanah diperoleh dari persamaan berikut (Arsyad, 2006) :

$100 \mathrm{~K}=1,292\left[2,1 \mathrm{M}^{1,14}\left(10^{-4}\right)(12-\mathrm{a})+\right.$

$$
3,25(b-2)+2,5(c-3)]
$$

Dimana:

$\mathrm{K}$ : erodibilitas tanah

$\mathrm{M}$ : persentase pasir sangat halus dan debu (diameter 0,1 - 0,05 dan 0,05 - 0,02 $\mathrm{mm}) \mathrm{x}(100$ - persentase liat $)$

a : persentase bahan organik (\% C-organik x 1,724)

$\mathrm{b}$ : kode struktur tanah yang digunakan dalam klasifikasi tanah

c : kelas permeabilitas profil tanah

\section{Faktor Topografi (Lereng)}

Penentuan faktor topografi yaitu panjang lereng (L) dan kemiringan lereng (S), 
dihitung sekaligus berupa faktor LS. lereng lebih kecil dari pengaruh Untuk menghitung panjang lereng dan kemiringan lereng (kemiringan lereng kemiringan lereng dapat dilakukan berpengaruh tiga kali dari panjang lereng melalui pendekatan sesuai dengan yang terhadap erosi).

tersaji pada Tabel 1, pengaruh panjang

Tabel 1. Penilaian kelas kelerengan (faktor LS) (Hardjowigeno dan Widiatmaka, 2007)

\begin{tabular}{cc}
\hline Kemiringan Lereng $(\%)$ & Nilai LS \\
\hline $0-8$ & 0,25 \\
$8-15$ & 1,20 \\
$15-25$ & 4,25 \\
$25-45$ & 9,50 \\
$>45$ & 12,00 \\
\hline
\end{tabular}

\section{Faktor Tanaman dan Pengelolaannya.}

Faktor ini ditentukan oleh jenis tanaman dan pengelolaannya atau pola tanam dalam setahun pertanaman.

Faktor Manusia yaitu Tindakan Konservasi Tanah.

Faktor tindakan konservasi tanah $(\mathrm{P})$ adalah nisbah besarnya erosi dari tanah dengan suatu tindakan konservasi tertentu terhadap besarnya erosi terhadap tanah yang diolah menurut arah lereng (Arsyad, 2006). Yang termasuk dalam tindakan konservasi tanah adalah penanaman dalam strip, pengolahan tanah tanah menurut kontur, guludan dan pembuatan teras.

\section{Penentuan Tingkat Bahaya Erosi (TBE)}

$$
\text { Tingkat bahaya erosi (TBE) }
$$
ditentukan berdasar atas perbandingan antara jumlah tanah yang tererosi dengan kedalaman (efektif) tanah tanpa memperhatikan jangka waktu kelestarian yang diharapkan, jumlah erosi yang diperbolehkan maupun kecepatan proses pembentukan tanah. Untuk menentukan tingkat bahaya erosi, Departemen Kehutanan (1986) menggunakan pendekatan tebal solum tanah yang telah ada dan besarnya erosi sebagai dasar (Hardjowi- 
geno dan Widiatmaka, 2007). Penilaian solum tanah dan besarnya tingkat bahaya erosi berdasar atas tebal bahaya erosi disajikan pada Tabel-2.

Tabel 2. Tingkat bahaya erosi berdasar tebal solum tanah dan besarnya bahaya erosi (jumlah erosi maksimum, A)

\begin{tabular}{cccccc}
\hline \multirow{2}{*}{ Tebal Solum $(\mathrm{cm})$} & \multicolumn{5}{c}{ Erosi Maksimum (A) (ton/ha/tahun) } \\
\cline { 2 - 6 } & $<15$ & $15-60$ & $60-180$ & $180-480$ & $>48$ \\
& & & & & 0 \\
\hline$>90$ & SR & S & S & B & SB \\
$60-90$ & R & B & B & SB & SB \\
$30-60$ & S & SB & SB & SB & SB \\
$<30$ & B & SB & SB & SB & SB \\
\hline
\end{tabular}

Keterangan : $\mathrm{SR}=$ sangat rendah, $\mathrm{R}=$ rendah, $\mathrm{S}=$ sedang, $\mathrm{B}=$ berat, $\mathrm{SB}=$ sangat berat (Sumber: Departemen Kehutanan, 1986 dalam Hardjowigeno dan Widiatmaka, 2007)

\section{HASIL DAN PEMBAHASAN}

\section{Sifat Fisik Tanah dan Fisiografi Lahan}

Analisis sifat fisik dan kimia tanah yang dilakukan adalah tekstur tanah, permeabilitas, struktur tanah, dan Corganik, serta pengukuran fisiografi lahan di lapangan meliputi kemiringan lereng dan panjang lereng. Hasil analisis sifat fisik dan kimia tanah serta pengukuran fisiografi lahan disajikan pada Tabel 3.

Struktur tanah merupakan gumpalan kecil dari butir-butir tanah. Gumpalan struktur terjadi karena butir-butir pasir, debu, dan liat terikat satu sama lain oleh suatu perekat seperti bahan organik, oksida-oksida besi, dan lain-lain (Hardjo- wigeno, 2007). Data pada Tabel 3 menunjukkan bahwa struktur tanah di daerah penelitian yaitu granular. Struktur tanah sangat ditentukan oleh tekstur tanah dan kandungan bahan organik tanah. Bentuk dan stabilitas agregat, serta persentase tanah yang teragregasi sangat berperan dalam menentukan tingkat kepekaan tanah terhadap erosi (Dariah, Rachman, dan Kurnia, 2004).

Tekstur tanah merupakan perbandingan antara banyaknya fraksi pasir, debu dan liat. Tekstur tanah di daerah penelitian meliputi liat, liat berdebu, lempung liat berdebu, dan debu. Jenis tanah yang ada di lokasi penelitian adalah Oksisol, Ultisol, Alfisol, dan Inseptisol. 
Tabel 3. Hasil analisis sifat fisik tanah, kimia tanah dan fisiografi lahan di daerah penelitian

\begin{tabular}{ccccccc}
\hline $\begin{array}{c}\text { Satuan } \\
\text { Lahan }\end{array}$ & Struktur & Tekstur & $\begin{array}{c}\text { C-org } \\
(\%)\end{array}$ & $\begin{array}{c}\text { Permeabilitas } \\
(\mathrm{cm} / \text { jam })\end{array}$ & $\begin{array}{c}\text { Kemiringan } \\
\text { Lereng }(\%)\end{array}$ & $\begin{array}{c}\text { Panjang } \\
\text { Lereng } \\
(\mathrm{m})\end{array}$ \\
\hline UL III 1 & Granuler & CL & 2,32 & 2,93 & 30 & 110 \\
UL III 2 & Granuler & SiCl & 1,85 & 2,88 & 11 & 110 \\
UL III 3 & Granuler & CL & 1,67 & 3,09 & 25 & 109 \\
UL III 4 & Granuler & C & 1,52 & 3,05 & 11 & 120 \\
UL III 5 & Granuler & C & 1,04 & 3,02 & 6 & 188 \\
\hline
\end{tabular}

Keterangan : $\mathrm{C}=$ liat, $\mathrm{CL}=$ liat berdebu, $\mathrm{SiCL}=$ lempung liat berdebu.

Tanah dengan kandungan debu lebih tinggi relatif lebih rentan terjadi erosi dibandingkan yang mengandung liat dan pasir (Arsyad, 2006). Hasil penelitian Dariah et al. (2004) menunjukkan bahwa tanah dengan rata-rata kandungan fraksi halus $>70 \%$, struktur tanahnya tergolong sangat mantap, erosi yang terjadi <2 ton/ha/tahun, dengan rata-rata aliran permukaan $<1,5 \%$ dari curah hujan efektif.

Hasil analisis C-organik sampel tanah menghasilkan nilai C-organik yang berkisar antara 1,04 - 2,32\%. Kadar Corganik tanah ditentukan oleh jumlah bahan organik (pupuk kandang) yang diberikan dan sisa-sisa tanaman yang tertinggal dalam tanah. C-organik sangat menentukan struktur tanah dan permeabilitas tanah. Bahan organik sangat berperan pada proses pembentukan dan pengikatan, serta penstabilan agregat tanah. Pengaruh utama bahan organik adalah memperlambat aliran permukaan, meningkatkan infiltrasi, dan memantapkan agregat tanah (Arsyad, 2006). Hasil penelitian Rachman et al. (2003) bahwa pengelolaan tanah dan tanaman yang mengakumulasi sisa-sisa tanaman berpengaruh baik terhadap kualitas tanah, yaitu terjadinya perbaikan stabilitas agregat tanah, ketahanan tanah, dan resistensi tanah terhadap daya hancur curah hujan (splash detachment).

Permeabilitas tanah menunjukkan kecepatan pergerakan air dalam tanah. Permeabilitas tanah sangat dipengaruhi oleh tekstur, struktur, dan bahan organik tanah. Hasil pengukuran permeabilitas tanah di lokasi penelitian yaitu berkisar antara 2,88 - 3,09 cm/jam. Berdasarkan klasifikasi permeabilitas maka termasuk kategori sangat lambat sampai sedang (Arsyad, 2007). 
Hasil pengukuran kemiringan konservasi tanah yang perlu dilakukan lereng lahan menunjukkan kemiringan petani pada pertanaman kentang di daerah lereng yang berkisar dari $6 \%$ sampai $30 \%$. penelitian. Prediksi erosi dilakukan Kemiringan lereng akan mempengaruhi berdasarkan curah hujan, sifat-sifat fisik jumlah dan kecepatan aliran permukaan. Semakin miring lereng, maka memperbesar jumlah dan kecepatan aliran permukaan, dan jumlah butir-butir tanah yang terpercik ke bawah oleh tumbukan butir hujan semakin banyak (Arsyad, 2006).

Panjang lereng diukur mulai dari titik pangkal aliran permukaan sampai suatu titik dimana air masuk ke dalam saluran atau sungai, atau di mana kemiringan lereng berkurademikian rupa sehingga kecepatan aliran berubah. Panjang lereng di daerah penelitian berkisar dari $109 \mathrm{~m}$ - 188 m. Aliran permukaan pada bagian atas lereng akan lebih kecil dibandingkan aliran permukaan pada ujung bawah lereng. Sehingga erosi yang terjadi pada bagian atas lereng lebih kecil dari pada bagian ujung bawah lereng. Semakin panjang suatu lereng maka semakin besar jumlah erosi yang terjadi (Arsyad, 2006).

Prediksi Erosi dan Tingkat Bahaya Erosi pada Pertanaman Kentang

Prediksi erosi dilakukan untuk mengetahui jumlah tanah yang hilang tanah, panjang dan kemiringan lereng, kualitas teras dan pola tanam yang diterapkan petani.

Hasil perhitungan prediksi erosi menggunakan persamaan Smith, et al. (2007) dengan rumus persamaan 1.1 diperoleh besarnya tanah yang tererosi disajikan pada Tabel 4. Data pada Tabel 4 menunjukkan bahwa erosi yang terjadi pada lahan pertanaman kentang termasuk kategori rendah, sedang, berat, dan sangat berat. Hal ini dibadingkan dengan standar tingkat bahaya erosi dari Departemen Kehutanan (1986, dalam Hardjowigeno dan Widiatmaka, 2007), yaitu pada tanah dengan tebal solum $60-90 \mathrm{~cm}$, erosi rendah $(<15$ ton/ha/tahun), sedang (15-60 ton/ha/tahun), berat (60-180 ton/ha/tahun), dan sangat berat (>180 ton/ha/tahun).

Perhitungan erosivitas hujan (R) dilakukan menggunakan rumus hubungan antara $\mathrm{EI}_{30}$ dengan curah hujan tahunan (Lenvain (1975, dalam Bols, 1978) sebagaimana tertera dalam persamaan rumus 7.3. Data pada Tabel 4 menunjukkan bahwa hasil perhitungan melalui erosi dan menganalisis teknologi 
erosivitas hujan (R) di Pattapang yaitu 1513,60.

Tabel 4. Prediksi erosi yang terjadi pada lahan pertanaman kentang di Pattapang

\begin{tabular}{lcccccr}
\hline $\begin{array}{l}\text { Satuan } \\
\text { Lahan }\end{array}$ & R & K & LS & C & P & $\begin{array}{c}\text { Erosi } \\
\text { (ton/ha/tahun) }\end{array}$ \\
\hline SL III 1 & 1513,60 & 0,4310 & 9,50 & 0,4 & 0,90 & 223,11 \\
SL III 2 & 1513,60 & 0,0412 & 1,20 & 0,4 & 0,75 & 22,45 \\
SL III 3 & 1513,60 & 0,0441 & 4,25 & 0,4 & 0,90 & 102,13 \\
SL III 4 & 1513,60 & 0,0491 & 1,20 & 0,4 & 0,40 & 14,27 \\
SL III 5 & 1513,60 & 0,0441 & 0,25 & 0,4 & 0,50 & 3,34 \\
\hline
\end{tabular}

Tabel 5. Tingkat bahaya erosi dan satuan lahan di pertanaman kentang

\begin{tabular}{lc}
\hline Tingkat Bahaya Erosi (TBE) & Satuan Lahan \\
\hline $\begin{array}{l}\text { Rendah } \\
(<15 \text { ton/ha/tahun) }\end{array}$ & SL III 4 dan SL III 5 \\
Sedang (15-60 ton/ha/tahun) & SL III 2 \\
Berat (60-180 ton/ha/tahun) & SL III 3 \\
Sangat Berat $(>180$ ton/ha/tahun & SL III 1 \\
\hline
\end{tabular}

Berdasarkan rumus perhitungan pengikisan oleh butir-butir air hujan nilai erodibilitas tanah (K) yang dan aliran permukaan (Arsyad, 2007). dikemukakan dalam persamaan (1.4), Erodibilitas tanah sangat penting untuk diperoleh nilai erodibilitas tanah pada diketahui agar tindakan konservasi dan daerah penelitian berkisar dari 0,0412 pengelolaan tanah dapat dilaksanakan (sangat rendah) sampai 0,4310 (sangat secara lebih tepat dan terarah. Veiche tinggi). Erodibilitas tanah dipengaruhi (2002) menyatakan bahwa konsep dari oleh sifat-sifat tanah yang mempengaruhi erodibilitas tanah dan bagaimana cara laju infiltrasi, permeabilitas, dan menilainya merupakan suatu hal yang kapasitas tanah menahan air, dan sifat- bersifat kompleks atau tidak sederhana, sifat tanah yang mempengaruhi ketahanan karena erodibilitas dipengaruhi oleh struktur tanah terhadap dispersi, dan banyak sifat-sifat tanah. Hasil penelitian 

Kurnia dan Suwardjo (1984) dalam Dariah et al. (2004) menunjukkan nilai erodibilitas beberapa jenis tanah di Pulau Jawa yaitu Oksisol 0,03-0,09 (sangat rendah), Ultisol 0,10- 0,16 (sangat rendah - rendah), Entisol 0,14 (rendah), Alfisol 0,22-0,23 (sedang), dan Vertisol 0,27 (sedang).

Penentuan nilai faktor LS menggunakan pendekatan seperti tertera pada Tabel 1, dan diperoleh nilai faktor LS pada daerah Pattapang yaitu berkisar dari 0,25 sampai 9,50. Kemiringan dan panjang lereng merupakan dua unsur topografi yang paling berpengaruh terhadap aliran permukaan dan erosi. Makin curam lereng, maka memperbesar jumlah dan kecepatan aliran permukaan dengan demikian memperbesar energi angkut air. Jika lereng permukaan tanah menjadi dua kali lebih curam, maka banyaknya erosi per satuan luas menjadi 2,0- 2,5 kali lebih banyak (Arsyad, 2006).

Faktor $\mathrm{C}$ atau vegetasi penutup tanah bernilai 0,4. Vegetasi penutup tanah sangat besar pengaruhnya terhadap aliran permukaan dan erosi. Pengaruh vegetasi terhadap aliran permukaan dan erosi dapat melalui intersepsi hujan oleh tajuk tanaman, mengurangi kecepatan aliran permukaan dan kekuatan perusak air, pengaruh akar dan kegiatan biologi yang berhubungan dengan pertumbuhan vegetatif dan pengaruhnya terhadap stabilitas struktur dan porositas tanah, dan transpirasi yang mengakibatkan kandungan air tanah berkurang (Arsyad, 2006).

Nilai $\mathrm{P}$ atau faktor pengelolaan bernilai $0,4-0,9$. Faktor pengelolaan sangat ditentukan oleh manusia atau petani yang mengelola lahan. Banyak faktor yang menentukan apakah manusia akan memperlakukan dan merawat serta mengusahakan tanahnya secara bijaksana sehingga menjadi lebih baik dan dapat memberikan pendapatan yang cukup untuk jangka waktu yang tidak terbatas. Faktor-faktor tersebut meliputi luas tanah pertanian yang diusahakan, sistem pengusahaan tanah, status penguasaan tanah, tingkat pengetahuan dan penguasaan teknologi, harga hasil usahatani, perpajakan, ikatan hutang, pasar dan sumber keperluan usahatani, dan infraArsyad, 2006).

Besarnya erosi yang terjadi pada pertanaman kentang di Pattapang berkisar dari 3,34 ton/ha/tahun sampai 223,11 ton/ha/tahun. Berdasarkan nilai tingkat bahaya erosi (TBE) (Tabel 5), maka erosi yang terjadi pada lahan pertanaman kentang yaitu lahan yang mengalami 

tingkat bahaya erosi rendah yaitu SL III 4 dan SL III 5.Lahan yang mengalami erosi sedang yaitu SL III 2.Lahan yang mengalami erosi berat yaitu SL III 3. Sedangkan lahan yang mengalami erosi sangat berat yaitu SL III 1. Lahan yang mengalami erosi sangat berat yang paling luas dengan tingkat erosi lebih besar dari 180 ton/ha/tahun.

Hasil perhitungan prediksi erosi yang terjadi pada lahan pertanaman kentang dengan kemiringan lereng $6 \%$ sampai $30 \%$ (landai sampai curam), dan panjang lereng $109 \mathrm{~m}$ sampai $188 \mathrm{~m}$ (Tabel 4), menunjukkan bahwa prediksi erosi yang terjadi rata-rata melebihi erosi yang dapat ditoleransikan, kecuali satuan lahan SL III 4 dan SL III 5. Keadaan ini memberikan petunjuk bahwa untuk pengelolaan lahan yang memiliki lereng landai sampai sangat curam pada pertanaman kentang, teknologi konservasi yang diterapkan oleh petani masih sangat minim sehingga belum mampu menekan laju kerusakan lahan yang diakibatkan oleh erosi. Penanaman tanaman dan pembuatan bedengan yang dilakukan oleh petani yaitu searah lereng. Semakin besar kemiringan lereng maka semakin cepat aliran permukaan yang menyebabkan erosi semakin meningkat.

\section{KESIMPULAN}

Prediksi erosi yang terjadi pada lahan pertanaman kentang menunjukkan bahwa besarnya erosi berkisar 3,34 ton/ha/tahun sampai 223,11 ton/ha/tahun. Perhitungan tersebut diperoleh dari nilai erosivitas hujan yaitu 1513,6, nilai erodibilitas tanah berkisar 0,0412 0,0491, nilai panjang dan kemiringan lereng yang berkisar $0,25-9,50$, nilai vegetasi penutup tanah yang berkisar 0,4 dan nilai faktor pengelolaan lahan berkisar $0,4-0,9$.

Tingkat bahaya erosi (TBE) pada lahan pertanaman kentang yaitu lahan dengan TBE sangat berat terjadi pada SL III 1, lahan dengan tingkat bahaya erosi berat terjadi pada SL III 3, lahan dengan tingkat bahaya erosi sedang terjadi pada SL III 2, serta lahan dengan tingkat bahaya erosi ringan terjadi pada lahan SL III 4 dan 5 dari total luas lahan yang ditanami kentang.

\section{UCAPAN TERIMA KASIH}

Terima kasih disampaikan kepada Ditlitabmas Dirjen Dikti Kementerian Pendidikan Nasional atas dana penelitian Hibah Kompetitif Unggulan Perguruan Tinggi T.A. 2013. 


\section{DAFTAR PUSTAKA}

Arsanti, I.W., dan M. Boehme. 2006. Sistem Usahatani Tanaman Sayuran di Indonesia: Apresiasi Multifungsi Pertanian, Ekonomi, dan Eksternalitas Lingkungan. Seminar Multifungsi Pertanian. Lido 26-27 Juni 2006. Badan Litbang Pertanian. Departemen Pertanian.

Arsyad, S. 2006. Konservasi Tanah dan Air. IPB Press. Bogor.

Asdak, C. 1995. Hidrologi dan pengelolaan Daerah Aliran Sungai. Gadjah Mada University Press. Yogyakarta.

BP-DAS Jeneberang Walanae.2003. PenLapangan Rahabilitasi Lahan dan Konservasi Tanah Daerah Aliran Sungai (DAS) Jeneberang, Provinsi Sulawesi Selatan. BP-DAS Jeneberang Walanae Provinsi Sulawesi Selatan dan LPPM Universitas Hasanuddin.Makassar.

Dariah A, H. Subagyo, C. Tafakresnanto, dan S. Marwanto. 2004. Kepekaan Tanah Terhadap Erosi. Dalam: Teknologi Konservasi Tanah pada Lahan Kering Berlereng. Edt. U. Kurnia, A. Rachman, dan A. Dariah. Pusat Penelitian dan Pengembangan Tanah dan Agroklimat. Badan Litbang Pertanian. Departemen Pertanian. Bogor.

Dariah, A., A. Rachman, dan U. Kurnia. 2004. Erosi dan Degradasi Lahan Kering di Indonesia. Dalam: Teknologi Konservasi Tanah pada Lahan Kering Berlereng. Edt. U. Kurnia, A. Rachman, dan A. Dariah. Pusat Penelitian dan Pengembangan Tanah dan Agroklimat. Badan
Litbang Pertanian. Departemen Pertanian. Bogor.

Dariah, A. dan E. Husen.2006. Optimalisasi Multifungsi Pertanian pada Usahatani Berbasis Tanaman Sayuran. Dalam Prosiding Seminar Multifungsi dan Revitalisasi Pertanian. Badan Litbang Pertanian, MAFF Japan, dan Asean Secretariat. Jakarta.

Hardjowigeno, S. dan Widiatmaka. 2007. Evaluasi Kesesuaian Lahan dan Perencanaan Tataguna Lahan. Gadjah Mada University Press. Yogyakarta.

Murtilaksono, K. 2009. Evaluasi Kebijakan Nasional Pengelolaan SDA dan Lingkungan di Daerah Aliran Sungai. Revitalisasi Kebijakan Nasional Pengelolaan Sumberdaya Alam dan Lingkungan Hidup. Lokakarya Nasional Kerjasama Sekolah Pascasarjana IPB dengan Kementerian Lingkungan Hidup RI, Tanggal 19 Maret 2009. Bogor.

Rachman, A., S. H. Anderson, C. Gantzer, and A. L. Thompson. 2003. Influence of Longterm Cropping System on Soil Physical Properties Related to Soil Erodibility. Soil Sci. Soc. Am. J. 67: 637-644.

Sinukaban, N. 2008. Pembangunan Daerah Berbasis Strategi Pengelolaan Daerah Aliran Sungai. Prosiding Seminar dan Kongres Nasional MK VI 17 - 18 Desember 2007, Cisarua-Bogor.

Smith, S.V., S.H. Bullock, A.H. Corona, E.F. Vizcaino, M.E. Rodriguez, T.G. Kretzschmar, L.M. Farfan, and 
J.M.S. Cesena. 2007. "Soil Erosion and Significanse for Carbon Fluxes in a Mountainous MediterraneanClimate Watershed". Ecological Applications Journal 17 : 1379 1387.

Veiche, A. 2002. The Spatial Variability of Erodibility and Its Relation to Soil Types: A Study from Northern Ghana. Geoderma 106: 110-120.

Wischmeier, W.H., and J.V. Mannering. 1969. Relation of Soil Properties to Its Erodibility. Soil Sci. Am. Proc. 33: 131-137.

Zubair, H. dan F. X. Djuhartono. 2001. Model Pengendalian Sedimen untuk Mempertahankan Kapasitas Waduk Bili-Bili, Sulawesi Selatan. Profiling Wilayah DAS Jeneberang. Pusat Penelitian Lingkungan Hidup (PPLH) - UNHAS. Makassar. 